\title{
INTERPERSONAL METAFUNCTION IN INTERACTIVE DIALOGUE MATA NAJWA METRO TV
}

\author{
Diyah Atiek Mustikawati [1], Sumarlam [2]
}

\author{
[1] diyah_mustikawati08@yahoo.co.id, [2] sumarlamwd@gmail.com \\ Universitas Sebelas Maret \\ Surakarta, Jawa Tengah, Indonesia
}

\begin{abstract}
The purpose of this study is to determine the interpersonal metafunction, modes and modalities contained in Mata Najwa inetractive dialog. This research is qualitative research. Determination of the sample using purposive sampling. Data collection techniques used recording and transcription. For data analysis, this research used content analysis through three strategic stages, namely stages of data collection, the data analysis stage, and the stage presentation of data. The results showed realizationof action in form of declarative clauses were dominant $65.33 \%$, while $34.30 \%$ interrogative clause and imperative clause $0.36 \%$. There is a mode of request and provide information, goods and services that fall within the proposals and propositions. The findings in this study modality is probability modalisasi of being $0.36 \%, 0.54 \%$ low probability modalisasi, high obligation modulation $1.64 \%$, the was $0.36 \%$ average modulation, and modulation inclination was $0.72 \%$.
\end{abstract}

Keywords: metafunction, interpersonal, mood, modality

\section{INTRODUCTION}

Language is a communication tool that is organized in the form of units of units, such as word, group of words, clauses, and sentences that expressed both verbal and written. There are a lot of definitions of language, and that definition is only one of them. We can compare these definitions with definitions including definitions of human language is a communication system that is expressed through the arrangement of sounds or write expressions that are structured to form a larger unit, such as morphemes, words, and sentences, which translated from English: "the system of human communication by means of a structured arrangement of sounds (or written representation) to form lager units, eg.morphemes, words, sentences" (Richards, Platt \& Weber, 1985, p. 153).

Oral use of language can be contained in a conversation or dialogue. Dialogue is one of wacan based on the types of use which shows the liveliness of its participants (Baryadi, 2002, p. 10). Dialogue takes place directly in the conversation and can occur in the electronic mass media as a communication tool, in this case the television so the information or message can be delivered in a clear, easily understood and seen visually.

One of television programs under consideration and deserves to be shown is the interactive dialogue najwa eye on metro tv. Mata Najwa is the program of talk show. It is performanced at Metro TV on 21.30 GMT every wednesday. Mata Najwa program guided by a nice presenter also beautiful journalist, she is Najwa Shihab. Most of the guest speakers who comes in this program represent the famous people, such as president, minister, governor, regent /mayor, member of parliament/ people's consultative assembly, and the others elite political.

Mata Najwa program is not only have a high educational value but by inviting significant figures of prominent political elite to make the program more attractive.The use of language in this clause that is used to build interpersonal communication among 
participants involved. On the other word with Surbakti (2013) in her research about stated that in analyzing the meaning of the utterance we can used metafunction of language. One of them is interpersonal metafunction.

Interpersonal is one of metafunction of language. Interpersonal metafunction relates to how do we interact through a language such as giving / asking for information, getting people to do something, and the ways we express our judgment and attitude - about things like possibility, need, and desire. This study willing to discuss interpersonal metafunction presented in an interactive dialogue Mata Najwa in Metro TV.

\section{METAFUNCTION Of LANGUAGE}

Metafunction language is a term stated by Halliday used to describe three different ways that occur simultaneously. Metafunction consists of (1) the meaning of the experiential, (2) the meaning interpersona, and (3) the textual meaning which also appears when the language is used. Metafunction is an emerging language and devices used in the study of semiotic linguistics to describe and explain the meaning (semantics) when the language (text) interpreted and explained. It has been called, LSF or Linguistic Functional Linguistics in assessing the meaning of the text by reviewing the meaning of the various functions of language (metafunction language). Experiential Metafunction examines the meaning of the text is based on the function of language in a way describe the reality of nature, because one function of language is observing function.Language reflects what is actually happening in the real world (language as reflection). Interpersonal metafunction has function to examine the meaning of the text is based on the function of language as a tool that can be exchanged when a person interacts with others to communicate its experience. In this function serves as a language of action (language as action). Meanwhile, as the third metafunction is textual matafunction, which is interpreted as a function of language that facilitates both metafunction previously, namely experiensial and interpersonal metafunction to be realized in the text.

Halliday's point of view towards the study of discourse analysis different from other functional theories. Systemic functional theory have a paradigm, that the functional properties of language is realized through metafui language consisting of experiential metafunction, interpersonal metafunction, and textual metafunction. Third metafunction is encoded lexicogrammar (lexis and grammar) which constructs the text. This text is realized lexicogrammar encode meaning in each level metafunction.

According to Halliday in LSF there are three main functions of language, because the language is built on three main objectives, namely; 1) discuss what is, what will and what had happened; 2) to interact or communicate ideas; 3) To produce both the above functions in an overall coherence. The third function is called with metafunction simultaneously realized in a clause or text.

\section{Ideational Metafunction}

Each text contains three functions at the same time that can be analyzed, namely ideational function, interpersonal function and textual function (Halliday, 1994, xiii, Matthiessen, 1992, p. 5), Enggins, 1994, p. 198-219, Saragih, 1995, p. 13-14) , These three functions are realized in the form of language function usage (language in use).

Ideational meaning is a function of language as a representation of experience. Components ideational meaning refers to the strength of the speaker as an observer (Halliday, 1978, p. 112). This is a function of the content of the language or languages as about something. This component informs that through language speakers encodes a cultural experience and the experience of individuals as members of a particular culture. In the ideational components, language has the function of representation. The language used to encode (encoding) human experience of the world. Language used to take picture of reality around human.

Ideational functions related to how language expresses human experience related to people, places, objects and activities that embody the physical and psychological environment. Ideational meaning embodied in the language through grammar transitive system. The key elements of transitive system is the process of occurrence (or everything that happens), participants (person, place or thing that is involved in the process) and the 
atmosphere of the event (place, time, manner, cause, etc.) associated with the process.

Ideational functions manurut Halliday (1994, p. 106) is part of the language as an expression of good experience what's in the external world around us and that is in the world of our own consciousness. Halliday (1992: p. 30) states that "the grammar of language is a theory of experience". Thus, the meaning of ideational representation of the text message.

One unit perfect experience realized in clause consists of three elements, namely the process,participant, and circumstance. The process refers to an activity or activity that occurs in a clause which, according to traditional grammar and formally called a verb or verb. Participants are restricted as people or objects that are involved in the process. Circumstance is a process that involves the environment in which participants take place (Halliday, 1994). The core of the experience is the process. Said, because the process of determining the number and categories of participants. Then, Halliday (1994); Martin (1992) stated that the process also determines circumstance indirectly by the level of probability; eg material and mental processes each occurred more frequently with circumstance, location, and manner.

\section{Interpersonal Metafunction}

Interpersonal metafunction is the action taken against the experience in social interaction. In other words, the function of interpersonal is the action by the language users in exchanging experiences linguistic unpresentable in function of experience (experiential meaning) (Saragih, 2006, p. 56). Interpersonal function forming social relationships, including the interpretation of probability by the speakers and the relevance of the message. Interpersonal function represent potential speakers as pelibat meaning in the process of interaction or as a speaker and a listener or between the writer and the reader. At the level of grammatical interpretation function clause is interpreted that clause formed from interaction in an incident involving the speaker or writer and the listener or reader. Halliday (1985, p. 6869) illustrates when two people use language to interact, one thing they do is perform a connection between them. In this case, the speakers of the language or speech function creates two types of roles or functions of speech are fundamental or function member or request.

Language as an interpersonal function has four action called protoaksi as an initial action which can further be lowered another action. The fourth action is the action statements, questions, offers and orders. This term refers to and is equivalent to the concept of speech function (Halliday, p. 1994) and speech acts (speech act) which is used in formal grammar.

Fourth protoaksi in the previous section is considered as an early action of the speakers. Of the four initial actions that can be lowered by four other acts in the form of answers or responses (responding), as in the following chart:

Tabel 1: Aksi Awal dan Aksi Jawab

\begin{tabular}{ll}
\hline Aksi Awal & Aksi Jawab \\
\hline $\begin{array}{l}\text { Pernyataan } \\
\text { “Hari ini kita belajar } \\
\text { bahasa Indonesia" }\end{array}$ & $\begin{array}{l}\text { Tanggapan } \\
\text { pernyataan } \\
\text { "Oh" }\end{array}$ \\
\hline $\begin{array}{l}\text { Pertanyaan } \\
\text { "Sudah sampai dimana } \\
\text { materi pelajaran kita?" }\end{array}$ & $\begin{array}{l}\text { Question } \\
\text { answer } \\
\text { "denotative } \\
\text { meaning now". }\end{array}$ \\
\hline $\begin{array}{l}\text { Perintah } \\
\text { “Kerjakan latihan no 1 } 1\end{array}$ & $\begin{array}{l}\text { Imperative } \\
\text { answer } \\
\text { sampai 2!" }\end{array}$ \\
$\begin{array}{l}\text { mam/its ok right } \\
\text { mam" }\end{array}$ \\
$\begin{array}{l}\text { Tawaran } \\
\text { "Saya saja Buk yang } \\
\text { membawakan buku itu." }\end{array}$ \\
\hline \multicolumn{1}{c}{ "thank you." } \\
\hline
\end{tabular}

There is a difference of opinion among experts regarding protoaksi LSF in language usage. Halliday (1994) argues protoaksi is the fourth initial action, other actions are derivative action because the action is derived from the four initial action. From an early action (protoaksi) can be lowered by four responsible action (response). Of the four responsible action responsible action can be lowered four positive and four negative responsible action. Of the various other actions can be derived various combinations of actions that already exist so that the number of actions that can be derived is not infinite. 
Martin (1992, p. 46) argues the other, the action of the base there are fourteen fourinitial action, four action responsible, three nirklausa (not clause), namely the call, greeting, and exclamation, and three action against nirclausa responsibility, that responsibility for the call, replied to the greeting, and answer to the appeal. From the fourteenth action of this nature can be said to consist of seven initial action, ie, statements, questions, offers, orders, calls, greetings and exclamations. And seven responsible action in response to the seventh such action.

Tabel 2: Aksi Dasar dan Realisasi

\begin{tabular}{|c|c|c|c|}
\hline No & Aksi Awal & $\begin{array}{l}\text { Aksi } \\
\text { Jawab }\end{array}$ & Realisasi \\
\hline 1 & Panggilan & & "Afni" \\
\hline 2 & & $\begin{array}{l}\text { Jawab } \\
\text { panggila } \\
\text { n }\end{array}$ & "Saya Buk!" \\
\hline 3 & Salam & & $\begin{array}{l}\text { "Selamat pagi } \\
\text { anak-anak" }\end{array}$ \\
\hline 4 & & $\begin{array}{l}\text { Jawab } \\
\text { salam }\end{array}$ & $\begin{array}{l}\text { "Selamat pagi } \\
\text { Buk" }\end{array}$ \\
\hline 5 & Seruan & & “Merdeka!” \\
\hline 6 & & $\begin{array}{l}\text { Jawaban } \\
\text { seruan }\end{array}$ & "Merdeka!" \\
\hline 7 & $\begin{array}{l}\text { Pernyataa } \\
\mathrm{n}\end{array}$ & & $\begin{array}{l}\text { "Bahasa } \\
\text { merupakan } \\
\text { alat } \\
\text { komunikasi" }\end{array}$ \\
\hline 8 & & $\begin{array}{l}\text { Jawaban } \\
\text { pernyata } \\
\text { an }\end{array}$ & "Oh" \\
\hline 9 & $\begin{array}{l}\text { Pertanyaa } \\
\mathrm{n}\end{array}$ & & $\begin{array}{l}\text { "Siapa yang } \\
\text { tidak hadir } \\
\text { hari ini?" }\end{array}$ \\
\hline 10 & & $\begin{array}{l}\text { Jawaban } \\
\text { pertanya } \\
\text { an }\end{array}$ & "Amir" \\
\hline 11 & Tawaran & & $\begin{array}{l}\text { "Biar saya saja } \\
\text { yang } \\
\text { mengambil } \\
\text { buku itu" }\end{array}$ \\
\hline 12 & & $\begin{array}{l}\text { Jawaban } \\
\text { tawaran }\end{array}$ & "terima kasih" \\
\hline
\end{tabular}

The action is determined by the social context. The relationship between the action of the strata meaning (semantics) and its realization in strata grammar (lexcicogrammar) is the probability (Saragih, 2006, p. 69). In the Indonesian context, when one meets with her closest friends, she can greet her closest friends to say where are you going ?, what are you doing ?. Both of these clauses (elliptical can be used to realize regards introgatif although the mode. The mode can have more than one meaning. It is caused by a social context.

There are regularities in language study in realizing or encode experience into the experience or linguistic form which later became a habit in analyzing the phenomenon of language. For example, mental experience is usually expressed with a mental process. Usage habits linguistic form as it is called realization of the common or usual (unmarked). However, in various situations often happen one experiences not realized by the linguistic form is prevalent. Realization of experience with unusual shapes that make 'sense of language' giving something unusual (unsigned) (Saragih, 2006). Realization of linguistic experience with markers (marked) by a sense of language or encoding unusual as it's called experience metaphor (metaphoric representation or grammatical metaphors).

\section{Textual Metafunction}

The textual metafunction is a language interpretation in its function as a message, which serves as a shaper of text in the language. This is interpreted as a function intrinsic to the language itself. In a sense berhubungkait language with situational aspects in which language (text) embedded in it. With this use of language serves to assemble experience in the circuit was formed linkages: one (unit) experience (in experiential meaning and interpersonal meaning) relevant to the experience that has been and will be presented before and after. meaning textual form of theme (theme) and rema (Rheme).

Study themes emerged from the understanding that language serves to convey the message. This message was delivered bersistem. This suggests that language has rules in order to convey a message to the order properly and regularly. The function of this language is called textual functions. The theme is the starting point of a message that is realized in the clause. The theme is expressed with the first element of the clause. Elements clause after theme called rema (Saragih, 2007, p. 8). 
The theme of the terms of its shape can be participants, process or sirkumstan form of words, phrases and sentences. If there is only one element in a clause that could potentially become the theme of these elements is called a simple theme and labeled with the name, the theme ', whereas if in a clause there is more than one element that could potentially be a theme it is said that theme as the theme complex.

According Saragih (2006, p. 112-114) complex theme is "metafunction component of the theme" are (1) Textual themes; clause as a message (message) - the successor or conjunctive linking clause by clause earlier in the text (2) Interpersonal themes; clause as an exchange (exchange) - modal aspects indicate the role of migration in exchange.

(3) Topical themes; clause as a representation (representation)representation as (participants, circumstance or processes).

\section{Modus}

Establishment of communication and interaction basically just played through the role of asking and giving. In bringing the two roles are two types of related commodities, namely information and goods and services. If both the variable and the role of crossclassified commodities, four types of action to come, as summarized in the chart below. The fourth variable is called protoaksi for the fourth action is the source of all action taken by users of the language (Saragih, 2006, p. 64) Tabel 3: Modus

\begin{tabular}{lll}
\hline Peran & \multicolumn{2}{c}{ Komoditas } \\
\cline { 2 - 3 } & informasi & $\begin{array}{l}\text { Barang } \\
\text { dan Jasa }\end{array}$ \\
\hline Memberi & Pernyataan & Tawaran \\
\hline Meminta & Pertanyaan & Perintah \\
\hline
\end{tabular}

Systemically, the fourth protoaksi parsed as follows: give information called a statement (statement), requesting information referred question (question), providing goods and services called the bid (offer), ask for goods and services is called a command (command).

The term action is used as the language used to perform an action or actions, such as action to make statement, inquiries, bids and orders. Action statements and questions are grouped into one category called proposition (proposition) because commodities are exchanged is information, deals and orders sedngkan action called proposal, because commodities are exchanged for goods and services.

Fourth protoaksi above is the realization of interpersonal meaning in a semantic strata. Meanwhile, in strata grammar, protoaksi fourth is realized by three of the conversational tone that is technically called a linguistic mode (mood). Mode mode consists of Declarative, Interrogative, and Imperative. Typically, action statements, questions and commands each realized by mode declarative, interrogative and imperative, while the bid action has no common mode as its realization. With demkian, 'offer' in a particular social context can be realized by one of the three modes; declarative, interrogative, or imperative. The relationship between the action on semantic strata with the mode at the level of grammar is summarized in the following chart:

Tabel 4: Hubungan Aksi pada Strata Semantik

\begin{tabular}{lll}
\hline Semantik & $\begin{array}{l}\text { Tata } \\
\text { Bahasa } \\
\text { (Modus) }\end{array}$ & Klausa \\
\hline $\begin{array}{l}\text { pernyataan } \\
\text { pertanyaan } \\
\text { perintah } \\
\text { tawaran }\end{array}$ & $\begin{array}{l}\text { deklaratif } \\
\text { interogatif } \\
\text { imperatif }\end{array}$ & $\begin{array}{l}\text { Dia } \\
\text { menyelasaikan } \\
\text { pekerjaan itu. } \\
\text { Apakah dia } \\
\end{array}$ \\
& - & yang \\
& & menyelesaikan \\
& & pekerjaan itu? \\
& & Selesaikan \\
& & pekerjaan itu! \\
& & Biar saya yang \\
& & menyelesaikan \\
& & pekerjaan itu. \\
\hline
\end{tabular}

\section{Modalitas}

Modality refers to the area of meaning that lies between yes and no, which is the boundary between positive and negative polarity on the function of said clause (Halliday 1985, p. 335, Halliday, 2004, p. 618). Meaning that realized in the functioning modality expressed attitudes, views, considerations, opinions, including doubts, confidence and certainty speakers to experience (experiential function). Gerot and Wignell (1994, p. 28) stated the same thing, that what the system modality is to parse the area of uncertainty (uncertainty) that lies 
between yes and no or boundary between polar positive and polar negatives are intended to demonstrate the limits choice between two polar the. Halliday and Matthiessen (2004, p. 147), Eggins (2004, p. 172) states, the modalities contained in semantic function clauses are meaningful exchange of information called the proposition; whereas semantic function clauses in the exchange of goods and services called the proposal.

Modalities divided into modalisasi and modulation. Modalisasi (in the philosophical semantics called epistemic modality) associated with the degree / level of reality, namely a space of meaning between positive and negative polarity of a proposition, namely to give and ask for information (Halliday 1985, p. 335). Eggins (2004, p. 172-174) says that modalisasi is part of the area modalities, which shows the different ways when the user language meyampaikan message, expressing attitudes and judgment. If the modalities used to declare about the probability (likelihood) or frequency (frequency) of a proposition, called modalisasi. If the modalities used to declare about bonds (must) or inclination (desire) a proposal, called modulation. Modalisasi is an expression of the attitude of the speaker toward what he says. This is how the speaker entered the text, revealing assessment of the certainty, the possibility or the frequency of occurrence or existence. Modalisasi always declared implicitly votes speakers. However, because people play with language, modalisasi can also explicitly expressed by the speakers, which could further clarify the speakers votes.

Halliday (in Eggins, 2004, p. 174) describes modalisasi can be done using a type of mud ajungsi (mood adjunct) which carries certain value each, such as: low: saya berpendapat (I reckon), saya kira (I guess). medium: saya pikir (I think), I guess (I suppose) high: I believe. Modalisasi position the speakers whether they denote the probability (likelihood) or usualitas (incidence) of the disclosure of the information and how the speakers positioned himself in between those values.

The probability indicates that the speakers revealed the assessment of likelihood of occurrence or existence of something. Probability refers to the speaker's commitment to a statement which lies between the positive and negative positions. Value of statements with probabilities lie in definite / not sure that was stopped at a positive position (yes) and negative (no). Therefore, the actual probability is definitely closer to the action than the possible execution, while perhaps closer to the negative polarity. Clauses $\mathrm{He}$ may come a probability with medium value and covering the same distance range, ie, He came and he did not come. He certainly came clause has a meaning closer to the implementation of the action rather than the negative polarity. Unlike the clauses he may come, semantically closer to Him did not come. Grades or degrees of meaning modalities tiered, related to how far or the values it up on the implementation of the functions of said (positive polarity) or how far the values it until the inclination is not the function of said (negative polarity) are disclosed in the proposition or proposal. In other words, the values specified in the meaning of a continuum (a continuum) with a limit of how the degree of probability of an activity carried out and how the degree of impossibility of an activity carried out within the limits of the other. Modalitas stop at the positive polarity which indicates a function of said done (100\%). Likewise, the modalities stop the negative polarity which indicates the function said is not done at all. Meaning closest to the positive polarity is classified as a modality with a high degree, while the closest to the negative polarity is called modality with low degrees. Between these two limits (positive and negative) stretched modalities with intermediate degrees. The table below shows that the positive polarity is at the top as limiting modality with a high degree, which states that the modalities high degree closer to the positive polarity, while the limit for modality with low degrees are at the bottom of the table as a negative polarity. In other words, the modalities with lower degrees closer to the negative polarity (Saragih, 2006, p. 93).

Hodge \& Kress, and Fairclough (in Saragih 2006, p. 94) says that the modalities cover all four types of meaning other than the meaning of probability, frequency, necessity and inclination) with variations in degree of proximity or the possibility of ongoing (or not ongoing) one action. In a sense, the modalities include some other meaning, such as causality 
(causality), appearance (appearance), and the range of (hedging).

Causality related to necessity in the causality of action with participants asked to take action. Meaning of membiarkan, membuat, andmemaksa each causality is the realization of a low, medium, and high as in clausegadis itu berbaring di pantai sambil membiarkan ombak laut menyentuh kakinya, Dia rajin belajar membuat orang tuanya gembira, dan pasukan kita memaksa musuh menyerah.

The appearance associated with the probability in which there are degrees of the possibility of an action. Meaning like gayanya (lagaknya, konon atau naga-naganya), kelihatannya (atau kedengarannya), dan kenyataannya, each of which is the appearance of the value of low, medium, and high as in clause In Dalam gayanya he like for help, Kelihatannya dia meminta tolong, dan Kenyataannya dia meminta tolong.

The range indicates the level of a person doubts language users to link it delivered by a field. The range includes ascertaining question (question tags) that is linked to the probability. Someone who stated range something tells us to doubt the correctness of it with something intended. Because of her doubts, she asked the question that asked for certainty. Thus, the meaning of such around, sort or kind of each the lower and middle ranges, such as the clause pembicaraan itu berlangsung sekitar masalah politik, Pembicaraan itu berkenaan dengan semacam gagasan politik. Meaning with a high degree of assurance can be realized by such a question is not it? as in clause membicarakan politik, bukan? Modalisasi and modulation is a complex system and interact in a certain way. Both can occur within the same clause (Eggins, 2004, p. 182).

\section{METHOD}

This research is about interpersonal metafunction Mata Najwa in the interactive dialogue on metro TV uses qualitative description. In line with Moleong (2006: p. 6) stated that qualitative research means to understang phenomenom about something faced by the subject forexample attitude, custome, perseption, motivation, and action, etc using holistic and descriptive way in form of word and language in a naturally special context also using scientific method.Then, the data used is the Mata Najwa video interactive dialogue on metro TV consists of three episodes are Bertaruh Di Jakarta, Politik Jenaka, and Menjaga Bhineka downloaded via youtube that is downloaded during the month of October 2016. The research data is data that is spoken of the characters in the dialogue. The data collection technique used is the method see and record (Sudaryanto, 2001). Researchers recorded video Mata Najwa interactive dialogue on metro TV by downloading this is because that shows on television are not repeated. In the next phase, researchers analyzed data used interactive model (Mile and Huberman in Sutopo, 2002) consist of data reduction, data display, and drawing conlusion also verification.

\section{FINDING AND DISCUSSION}

\section{Analysis of Action and Realization of the Interactive Dialogue Mata Najwa on Metro TV}

From the results of research on interpersonal metafunction Mata Najwa interactive dialogue on Metro TV can be argued that of the three episodes of the interactive dialogue found 548 clause which comprises clauses / sentences in the form of interrogative, imperative and declarative. The findings of the sentence Interogative 188 or $34.30 \%$, of which Mata Najwa program is an interactive program that involves liveliness dialogue both speakers and hearer. The use of interrogative sentences are intended to provide questions, stimulus to the hearer with the ultimate goal of all the information can be delivered properly. It could not be separated from the host's expertise is in providing Najwa Shihab questions. The quality and insightful questions that direct delivery strategy stab to the heart or the subject matter is characteristic of Nana question. This causes difficulties for figure to guest star in Mata Najwa.

Furthermore, the findings second is Imperative sentences, the present study found the use of the imperative sentence as much as 2 clauses or $0.36 \%$. This imperative sentences are used at the end of the pause before an ad with a message or information that the audience and the audience in the studio that did not move and kept waiting until the 
commercial break is completed so that the event can be resumed.

The use of declarative sentences Mata Najwa interactive dialog lists many as 358 clauses or $65.33 \%$. That is a declarative sentence is a sentence which found that contents deliver the statement addressed to the judgments or in accordance with the chosen theme, but this sentence can be given favorable comments from presenternya own or viewers or listeners when deemed necessary. In the interactive dialogue Mata Najwa this, declarative sentences as well as answers to questions either directly or indirectly supplied. Therefore, it can be said that the interrogative sentences used by the presenter to have a relationship and orderliness with declarative sentences given by the informant.

\section{Analisis Modus Dialog Interactive Mata Najwa di Metro TV}

As we know that the modus(mood) or in the field of linguistics called the mood is a clause that realize the interpersonal meaning (Santosa, 2001, p. 105). Metafunction interpersonal contained in the interactive dialogue Mata Najwa is related to the realization of interaction between participants, which can be classified into two, giving and asking. While something given or requested may include such information, and the goods or services (goods and services). Here is an example of the use of modus in interactive dialogMata Najwa:

\begin{tabular}{|c|c|c|}
\hline & $\begin{array}{l}\text { barang dan } \\
\text { layanan }\end{array}$ & Informasi \\
\hline $\begin{array}{l}\text { Mem } \\
\text { - } \\
\text { beri }\end{array}$ & $\begin{array}{l}\text { kita harus } \\
\text { memberikan } \\
\text { peluang dan } \\
\text { ketrampilan } \\
\text { mereka untuk } \\
\text { mencari nafkah } \\
\text { dengan halal. }\end{array}$ & $\begin{array}{l}\text { kita sudah } \\
\text { menyampaikan } \\
\text { bahwa aturan main } \\
\text { dalam unjuk rasa } \\
\text { atau } \\
\text { menyampaikan } \\
\text { pendapat itu diatur } \\
\text { dalam undang- } \\
\text { undang, kamipun } \\
\text { juga akan ikut } \\
\text { dalam aturan itu }\end{array}$ \\
\hline \multirow[t]{2}{*}{$\begin{array}{l}\text { Me- } \\
\text { mint } \\
\text { a }\end{array}$} & $\begin{array}{l}\text { tetap di Mata } \\
\text { Najwa bertaruh } \\
\text { di Jakarta! }\end{array}$ & $\begin{array}{l}\text { apakah ini yang } \\
\text { anda khawatirkan? }\end{array}$ \\
\hline & Proposal & Proposisi \\
\hline
\end{tabular}

Based on the clause in the table above can be explained that the mode or mood made up mode declarative, interrogative and imperative also called action statements, questions and commands each realized by mode declarative, interrogative and imperative, while the action of bids has no mode prevalent as realization. Thus, the offer contained in the interactive dialogue najwa eye can be realized by one of the three modes

\section{Analisis Modalitas Dialog Interactive Mata Najwa di Metro TV}

In the study found form of modality consisting of modalisasi and modulation which in any type of modality assessed by the percentage of the clauses contained in the interactive dialogue were presented as follows:

\section{Modalisasi}

(1) Modalisasi Probalilitas Sedang

a. Nah inilah yang akan kita perkuat terutama juga bagaimana menciptakan transportasi. (D82)

b. kita akan bicara bagaimana mereka melihat situasi negeri ini dari kacamata yang berbeda (D 385)

(2) Modalisasi Probalilitas Rendah $(0.54 \%)$

a. Mungkin dalam beberapa caption terlihat mas agus tampil dengan merah putih ditangannya, (D217)

b. berarti masih mungkin ada ya? (D305)

c. oh masih mungkin ada ya (D307)

\section{Modulasi}

(1) Modulasi Obligasi Tinggi $(1,64 \%)$

a. yang pertama, kita harus memberikan peluang mereka untuk mencari nafkah dengan halal, kemudian mereka diberikan tambahan skill set untuk bisa juga masuk ke lapangan pekerjaan dan juga bisa berkompetisi dengan yang lainnya. (D 72)

b. Artinya kita harus peduli mereka ini perlu mendapatkan support untuk mendapatkan keterampilan, karena ketika memiliki keterampilan tentunya mereka memiliki peluang yang lebih besar untuk bekerja. (D73)

c. transportasion haps itu juga harus diperkuat.(D83) 
d. kita harus rasional melihat apa progress yang terjadi dijakarta tetapi kita cari mana yang bisa kita perbaiki. (D 198)

e. tentu harus ada spes khusus buat pejalan kaki (D200)

f. Dan harus mencerminkan bhineka tunggal ika. Itu dari saya. (D 223)

g. kita harus melindungi itu juga (D 483)

h. kita harus waspadai penyusupan dari kelompok-kelompok khilafah. (D 522)

i. TNI harus menjaga kebhinekaan tunggal ikaan, karena dengan demikian Indonesia bisa menjadi bangsa majemuk yang kuat dan solit (D534)

\section{Modalitas modulasi obligasi sedang (0.36\%)}

a. kita akan lihat visi misi dan program aksi yang akan sudah anda masukkan di Kpud, ini visi misinya menuju Jakarta yang lebih maju, aman, adil, dan sejahtera. (D 73)

b. pada saatnya akan saya ceritakan itu, karena sekarang belum masa kampanye dan itu tidak elok bagi saya untuk menceritakan program aksi secara langsung. (D89)

\section{Modalitas modulasi Inklinasi Sedang (0.72\%)}

1. saya ingin mendudukkan permasalahannya dulu bahwa bagi kami, bagi mas agus NKRI itu harga mati.(D 217)

2. tapi kalau mereka ingin menjadi mulia dan memiliki jiwa besar maka itu mumgkin lebih afdol atau lebih baik untuk dihentikan. (D 227)

3. itu yang anda inginkan? (D 230)

4. saya ingin minta komentar dari teman-teman yang ada (D 394)

Based on the above data display can be stated that not all types of modalities contained in Mata Najwa speech interactive dialogue. Types of modalities that emerged is the level of probability, bonds and inclination. 0:36 Modalisasi\% probabilisasi being marked with "ingin. And modalisasi 0:54\% lower probabilitsasi marked with a "mungkin". Furthermore, the modulation of the bonds marked a "harus" of $1.64 \%$, whereas in the level was at $0: 36 \%$ is marked with "akan".
Furthermore, exposure levels were $0.72 \%$ modulation is characterized by "want"

This research focuses on interpersonal function based on Halliday and Matthiessen (2004:108). In this terms interpersonal function means when we use language has several function and purposes they are tointeract with other people, to establish and maintain relationships, to influence behavior, to express our own point of view, to elicit or change the point of view of others. The researcher chose Mata Najwa program because in the dialogue especially the interaction between presenter Najwa Shihab and the guest star is so attractive in order to build the chemistry and find a lot of importance information. In that interaction dialogue, there are varieties clauses where the function associated with particular grammatical structures they are; statements by declarative clauses, questions by interrogative clauses, commands by imperative clauses.

Then, Interpersonal function in Mata Najwa interactive dialogue has its own system of meanings: Four basic speech roles as identified by Halliday and Matthiessen (2004, p. 108) are giving informationstatement, demanding information, question, giving goods and servicesoffer demanding goods and services command. All of the clauses have different purposes and information based on the theme are choosen.

\section{CONCLUSION}

Based on the discussion can be concluded that indicate realization in declarative clauses dominant $65.33 \%$, while $34.30 \%$ interrogative clause and imperative $0: 36 \%$ clause. There is a mode of request and provide information, goods and services that fall within the proposals and propositions. The findings in this study modality is probability modulation $0.6 \%$, then $0.54 \%$ low probability, high obligation modulation $1.64 \%$, the average obligation modulation was $0.36 \%$, and modulation inclination was $0.72 \%$. With interpersonal meaning used in mata najwa program related to the way how do we make good interaction in communication in order to giving information, making people do something, and expressing opinion, attitude through language. 


\section{REFERENCE}

Eggins, S. An Introduction of Systemic Functional Linguistic. (1994). London: Pinter

Ernawati Br Surbakti. (2013). Genre dan Metafungsi Bahasa. Khutbah 'Idul Adha' Oleh Dr. Tgk. H. Rusli Hasbi, LC, M.A. Di Lapangan Hiraq-Lhokseumawe. Jurnal Metamorfosa, 1, 2338-0306

Halliday, M. A. K. (2004). An Introduction to Functional Grammar. Second edition. London: Edward Arnold.

Halliday, M., and C. Matthiessen. (2004). An Introduction to Functional Grammar (3rdEdition), London: Arnold.

Mahsun. (2010). Metode Penelitian Bahasa. Jakarta: Rajagrafindo Persada.

Moleong, Lexy J. (2006). Metodologi Penelitian Kualitatif. [Edisi Revisi]. Bandung: Rosdakarya.

Praptomo Baryadi, I. (2002). Dasar-dasar Analisis Wacana Dalam Ilmu Bahasa. Yogyakarta: Pustaka Gondho Suli

Richards, J., Platt, J. \& Weber, H. (1995). Longman Dictionary of Applied Linguistics. Harlow: Longman.

Saragih, A. (2005). Introducing Systemic Functional Grammar. FBS, Universitas Negeri Medan (tidak diterbitkan)

Saragih, A. (2006). Bahasa dalam Konteks Sosial: Pendekatan Linguistik Fungsional Sistemik terhadap Tata Bahasa dan Wacana. Medan: Pascasarjana Unimed Press.

Santoso, Riyadi. (2001). Semiotika Sosial: Pandangan terhadap Bahasa. Surabaya: Pustaka Eureka.

Sudaryanto. (1998). Metode Linguistik: Metode dan Aneka Teknik Pengumpulan Data Bagian Pertama. Yogyakarta: Gadjah Mada University Press 